\title{
Quantifying the effects of settlement size on urban heat islands in fairly uniform geographic areas
}

\author{
Minghong Tan*, Xiubin Li \\ Key Laboratory of Land Surface Pattern and Simulation, Institute of Geographic Sciences and Natural Resources Research (IGSNRR), Chinese Academy of
} Sciences (CAS), Beijing 100101, PR China

\section{A R T I C L E I N F O}

\section{Article history:}

Received 9 February 2015

Received in revised form

18 April 2015

Accepted 21 May 2015

Available online 29 May 2015

\section{Keywords:}

Effects

City size

Urban heat island

Plain area

\begin{abstract}
A B S T R A C T
City size is closely related to urban heat island intensity (UHII). To examine the relationship more accurately, it is necessary to eliminate the effects of landforms and climatic differences on urban heat islands (UHIs), through selecting settlement clusters in a large plain within a similar biome as the study area. This study selected 1124 land use clusters (cities, towns, and big rural settlements) and demarcated surrounding buffer areas; each buffer width equaled the radius of the clusters. The results showed that $\mathrm{UHI}$ increased with growth in cluster size, and the relationship could be described using a logarithmic function. For clusters with an area $>2 \mathrm{~km}^{2}$, the city size accounted for about $60 \%$ of the variance in UHII during the night and only about $30 \%$ during the day. For clusters with areas of $<2 \mathrm{~km}^{2}$, the uncertainty in the relationship increased significantly and the relationship became very weak. In addition, our study showed that daytime UHII was higher than nighttime UHII, particularly for large cities with a size $>10 \mathrm{~km}^{2}$.
\end{abstract}

๑) 2015 Elsevier Ltd. All rights reserved.

\section{Introduction}

The urban heat island (UHI) effect is the difference between temperatures measured in urban areas and those measured in surrounding rural areas (Hamada \& Ohta, 2010; Nakayama \& Fujita, 2010; Zhang, Zhong, Deng, \& Wang, 2009). It is one of the most widely documented climatological effects arising from human modification of the atmospheric environment (Oke, 1973; Kalnay \& Cai, 2003; Wong \& Yu, 2005). With rising global warming, the intensity of UHI effects is also likely to increase in the future (Oliveira, Andrade, \& Vaz, 2011). UHIs influence not only local climate and energy consumption, but also air quality, biodiversity and ecosystem function, and human health (Grimm et al., 2008; Ma, Kuang, \& Huang, 2010). For instance, a $1{ }^{\circ} \mathrm{C}$ increase in temperature increases peak electricity demand by $2-4 \%$ when temperatures exceed $15-20^{\circ} \mathrm{C}$ (Lin, Wu, Zhang, \& Yu, 2011).

$\mathrm{UHI}$ is affected by various factors, including city size, impervious surfaces (low albedo, high heat capacity, decrease in evapotranspiration), topography, anthropogenic heat release, and meteorological conditions (Bart, 2010; Grimm et al., 2008; Jin, Kessomkiat,

\footnotetext{
* Corresponding author.

E-mail address: tanmh@igsnrr.ac.cn (M. Tan).
}

\& Pereira, 2011; Lin et al., 2008; Nichol, 2005). Compared with the other factors, city size has not been studied extensively (Steeneveld et al., 2011); however, it is important to understand its effects on UHI for climatic modelling, weather forecasting, and urban planning (Oke, 1973). These points are of particular interest for developing countries that are undergoing rapid urbanization ( $\mathrm{Wu}, \mathrm{Ye}$, Shi, \& Clarkec, 2014).

Currently existing literature mainly discusses the relationship between the magnitude or the extent of the UHI effect and city size, through selecting individual case studies or a limited number of cities (Cai, Du, \& Xue, 2011; Hung, Uchihama, Ochi, \& Yasuoka, 2006; Zhou, Rybski, \& Kropp, 2013), such as Tokyo, Beijing, and London. For instance, Hung et al. (2006) examined six Asian mega cities and conclude that Tokyo, which has the largest population, also has the most severe UHI effect in terms of magnitude (up to $12.8^{\circ} \mathrm{C}$ ) and extent (up to $8067 \mathrm{~km}^{2}$ ) based on the summer of 2001 . Oke (1973) analyzed the differences between 10 settlements in Canada with populations from 1000 to 2 million. These studies all showed that city size exerts significant effects on urban heat island intensity (UHII).

The use of remote sensing data (land use and land surface temperature) makes it possible to study the UHII of a large number of cities. Peng et al. (2012a, b) discussed the UHII of 419 global large cities and the potential biophysical and socio-economic driving 
factors using Moderate Resolution Imaging Spectroradiometer (MODIS) data. However, because their study selected large cities with populations $>1$ million and could not examine the full range of city sizes, the effects of city size on UHII were not estimated effectively. Thus, they concluded that city size has no obvious effect: the urban area obtained from MODIS land use explained $<3 \%$ of the heat island differences between cities on a global scale (Peng et al., 2012a, b; Schwarz, 2012).

For the systematic assessment of UHI effects in all cities and towns in Europe, Zhou et al. (2013) initially presented a statistical approach, and argued that the relationship between urban cluster and city size can be closely aligned using an empirical sigmoid model. In their study, because the effects could be masked by climatic differences, landforms, and other socio-economic factors due to the large area of the study region (Peng et al., 2012a,b), it was difficult to accurately estimate the contribution of city size to the variations in UHII. For instance, widely distributed water bodies, including rivers, lakes, and even seas on a continent, may distort the spatial pattern of UHI and the effects of city size on UHI (Fabrizi, Bonafoni, \& Biondi, 2010; Oke, 1973; Tan \& Li, 2013); although, water bodies are excluded from the calculation of the mean land surface temperature (LST) of the areas surrounding urban clusters (Zhou et al., 2013). In addition, different ecological contexts can also significantly affect the amplitude of UHII (Imhoff, Zhang, Wolfe, \& Bounoua, 2010). Thus, to estimate the effects of city size on UHII more accurately, it is necessary to eliminate non-urban climatic effects (Oliveira et al., 2011).

To eliminate the effects of landform on UHI, we must select a region with several ideal conditions. First, it is important to select a large plain, because a uniform plain can control the effect of topographical factors on UHII. Second, the cities or towns on the large plain should have similar biomes to eliminate the effects of vegetation cover on UHII. Third, a plain with fewer water bodies would help to control the effects of water bodies on UHII. Based on these criteria, we selected the Huabei Plain in China to examine the relationship between city size and UHII. In this area, the predominant land use is arable land and built-up areas, which occupied $72.2 \%$ and $10.1 \%$ of all land area in 2010, respectively. Further characteristics of this area will be introduced in the next section.

Previous studies concluded that UHII was most significant in summer, less pronounced during spring and fall, and least significant in winter (Imhoff et al., 2010; Kłysik \& Fortuniak, 1999; Zhou et al., 2013). Research related to our study area has also found that UHII is greatest in summer (Cai et al., 2011; Wang et al., 2007). Therefore, this study focuses on the relationship between city size and UHII in summer, during the day and night.

\section{Study areas}

The area chosen for this study was the Hebei Plain in North China, with an area of about $85,000 \mathrm{~km}^{2}$ (Fig. 1). The plain has very flat topography. Hebei Plain is one of the most important agricultural areas, and one of three most developed regions in China. In 2010, the total population and urban population of the study area were 104 million and 57 million, respectively, according to China's Sixth Census. The urban populations of the two largest cities in the study area, Beijing and Tianjin, were 16.7 million and 11.5 million in 2013, respectively.

Hebei Plain lies in the warm temperate zone and its annual precipitation (500-600 $\mathrm{mm}$ ) and runoff are concentrated between June and August (Wang, Jin, Nimmo, Yang, \& Wang, 2008). According to data from 13 China Meteorological Administration weather stations in this region, the daily air temperature maximum values varied slightly across the stations during the study period from July 4th to July 11th, 2010. For instance, on July 5th, 2010, the maximum air temperature varied from 37.4 to $40.8{ }^{\circ} \mathrm{C}$, and the mean air temperature varied from 30.6 to $33.7{ }^{\circ} \mathrm{C}$ (Table 1 ). Similarly, the wind speed also varied slightly across the stations. Thus, the geographical features present an ideal region for analyzing the effects of city size on UHII.

\section{Data and methods}

This study used 1-km MODIS LST data, which were composites of 8 day LST maximum values and were obtained from the Goddard Space Flight Center (http://ladsweb.nascom.nasa.gov/data/search. html) for the study period from July 4th to July 11th, 2010. UHIIs were calculated using Terra MODIS LST data daytime LST (13:30 h) and nighttime LST $(1: 30 \mathrm{~h})$. The accuracy of the MODIS LST data was found to be better than $1 \mathrm{~K}$ in most clear-sky cases by comparison with in situ measurements (Wan, 2008).

The land use data were mainly interpreted from Landsat TM/ ETM data. The data were provided by the "Environment Survey of Past Decade (2000-2010) with Remote Sensing Tool in China" project group (RCEES, 2013). The original data consisted of six main classes of land use types, which were cropland, forest, grassland, built-up area, water body, and other, and 38 subclasses. On the land use map, the areas with impervious surfaces covering more than $50 \%$ of the land were regarded as built-up areas. In our study, the land use types were re-grouped into four types: built-up area, cropland, water bodies, and other types. Similar to the study of Zhou et al. (2013), this study also used cluster area as an indicator of city size; this indicator has been reported to be a better method for monitoring UHI effects than urban population (Hamdi, 2010). In this study, cities, towns, and big rural settlements were all regarded as clusters, because some rural settlements in the study region were very large. Thus, 1124 clusters were selected (Fig. 1).

In this study, to calculate the average LSTs for clusters or the surrounding areas, we masked out water bodies in the study area with ArcGIS 9.3 software (Fig. 2), since surface water can significantly decrease LST, which in turn can distort the effects of city size on UHII. In addition, all urban pixels were removed, to calculate the average values of the LST of the surrounding areas more accurately. Thus, the surrounding area of a cluster was defined as all the nonurban and water body pixels.

In UHII studies, the scope of the surrounding area for different sizes of cities must be defined. In the existing literature, the scope is quoted to be a similar area to that of the urban area (Peng et al., 2012a,b; Zhou et al., 2013). In this study, we placed a buffer zone around each cluster as the surrounding area, and the buffer width equaled the radius of the cluster. The radius of a cluster $\left(C^{2} t_{1}\right)$ was calculated using Equation (1):

City $_{R}=\sqrt{\frac{S}{2 \pi}}$

in which $S$ is the area of a settlement cluster. This method is very simple and the radius for a large number of clusters can be easily calculated with ArcGIS software. Streutker (2002) uses a similar method to define the scopes of UHIs; however, the method is complicated and cannot be easily used for large numbers of clusters. According to our method, the surrounding area for a cluster is larger than that calculated by the method used in Peng et al. (2012a,b) and Zhou et al. (2013).

The mean LST of a cluster ( Tcluster $_{i}$ ) can be calculated using Equation (2):

Tcluster $_{i}=\frac{1}{n} \times \sum_{n=1}^{n}$ Pixel $_{n}$ 


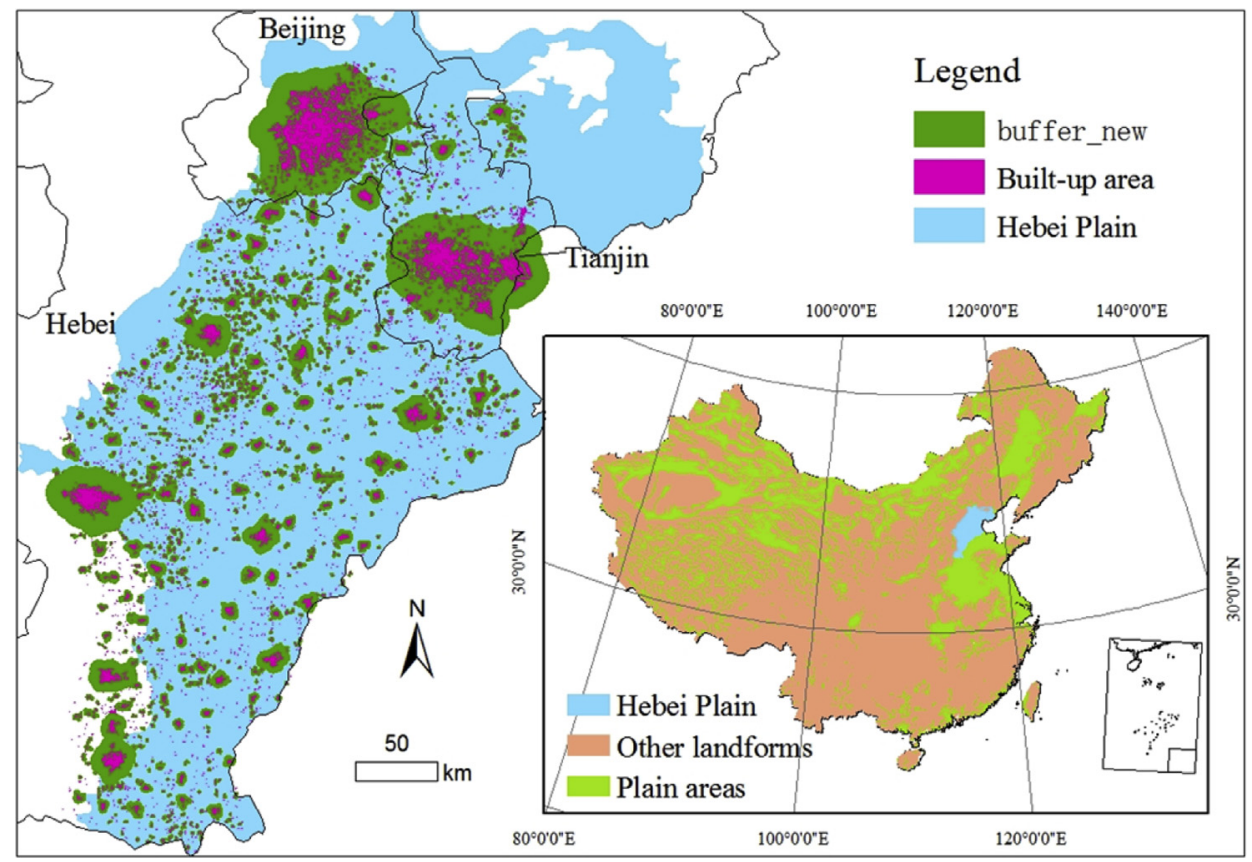

Fig. 1. Clusters and surrounding areas in this study. Map was created in ArcGis 9.3 (Environmental Systems Resource Institute, ArcGis 9.3 ESRI, Redlands, California).

Table 1

Wind speed and air temperature of 13 stations in the study area on July 5th, 2010.

\begin{tabular}{lllll}
\hline Station & $\begin{array}{l}\text { Wind } \\
\text { speed }(\mathrm{m} / \mathrm{s})\end{array}$ & $\begin{array}{l}\text { Mean air } \\
\text { temperature }\left({ }^{\circ} \mathrm{C}\right)\end{array}$ & $\begin{array}{l}\text { Min. air } \\
\text { temperature }\left({ }^{\circ} \mathrm{C}\right)\end{array}$ & $\begin{array}{l}\text { Max. air } \\
\text { temperature }\left({ }^{\circ} \mathrm{C}\right)\end{array}$ \\
\hline 1 & 1.4 & 30.8 & 22.7 & 40.8 \\
2 & 1.4 & 32.2 & 23.2 & 40.2 \\
3 & 2.5 & 33.7 & 25.0 & 40.6 \\
4 & 1.7 & 32.3 & 25.9 & 39.0 \\
5 & 2.5 & 31.9 & 26.3 & 38.9 \\
6 & 2.7 & 30.6 & 21.4 & 38.1 \\
7 & 1.8 & 31.2 & 24.4 & 38.7 \\
8 & 1.8 & 33.7 & 27.3 & 40.2 \\
9 & 1.6 & 31.9 & 27.0 & 39.1 \\
10 & 1.9 & 33.0 & 27.3 & 38.2 \\
11 & 1.9 & 32.8 & 25.7 & 38.6 \\
12 & 1.9 & 32.5 & 27.1 & 38.5 \\
13 & 1.9 & 32.0 & 27.6 & 37.4 \\
\hline
\end{tabular}

Here, Pixel $_{n}$ is the value of LST of Pixel $n$. The mean LST of the surrounding area (Tsurr ${ }_{i}$ ) was then calculated using the same method. The calculation can be performed using the Zonal Statistics tool as a table in the ArcGis 9.3 software. The UHII of the cluster $\left(U H I I_{i}\right)$ can be calculated using Equation (3):

$\mathrm{UHII}_{i}=$ Tcluster $_{i}-$ Tsurr $_{i}$

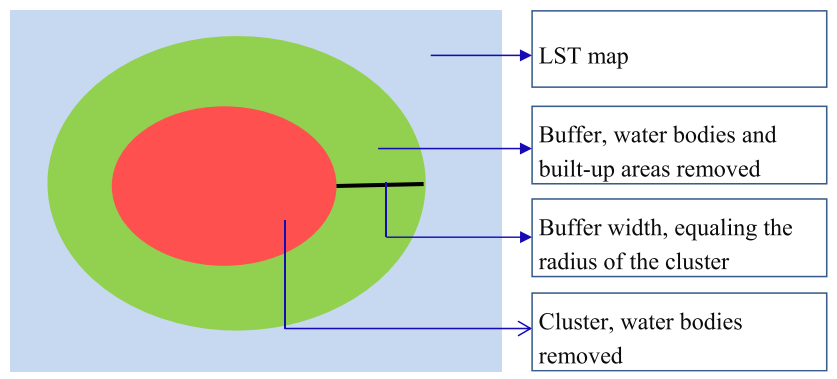

Fig. 2. Definitions of a cluster and its surrounding area.

\section{Results}

Fig. 3 shows that the mean LST was much lower at night than during the day. For the whole study area, the mean daytime and nighttime LST values were 24.2 and $40.0^{\circ} \mathrm{C}$, respectively. Spatially, along the west Beijing-Baoding-Shijiazhuang belt (Fig. 3), the daytime LST was significantly higher than the other areas. Baoding and Shijiazhuang had urban populations of 1.1 million and 2.8 million in 2010, respectively. In contrast to the daytime LST, the nighttime LST had a continuous spatial distribution along the Beijing-Baoding-Shijiazhuang belt.

Fig. 4 presents the effects of cluster size on UHII. For highranking clusters (large clusters), the UHII was greater than for the low-ranking clusters, both during the day and the night. This is more obvious in Fig. 5, which shows that the larger clusters had a greater UHII. For clusters with a size of $>100 \mathrm{~km}^{2}$, both day and night UHIIs were very high, and their medians were both greater than $2{ }^{\circ} \mathrm{C}$.

UHII variations were greater in the day than at night (Fig. 4 and Fig. 5). In Fig. 5, the length of the box, which represents the interquartile range, may also reflect the degree of dispersion. During the daytime, the lengths of the boxes are much longer than those at night for different cluster sizes. Further analysis of all 1124 clusters demonstrated that the daytime standard deviation (a measure of dispersion around the mean) was 1.03 , which was much higher than that for the nighttime value of 0.49 .

In the study area, the daytime UHII was higher than the nighttime UHII. For clusters $>100 \mathrm{~km}^{2}$ in size, the average day and night UHII values were 2.99 and 2.30, respectively. Fig. 5 also confirms this. In nearly every group, the median for daytime UHII was higher than that for nighttime. This confirmed that the mean daytime UHII was greater than nighttime UHII for clusters with an area $>2 \mathrm{~km}^{2}$.

As the cluster size increased, UHII for both day and night increased quickly. To quantify the relationship, a logarithmic form of cluster size was used (Fig. 6). UHII increased with increasing cluster size. For clusters with an area $>2 \mathrm{~km}^{2}$, the value of $\mathrm{R}^{2}$ reached 0.580 . This means that the cluster size explained about $60 \%$ of the variance in UHII, since $\mathrm{R}^{2}$ is the percentage of the (dependent 


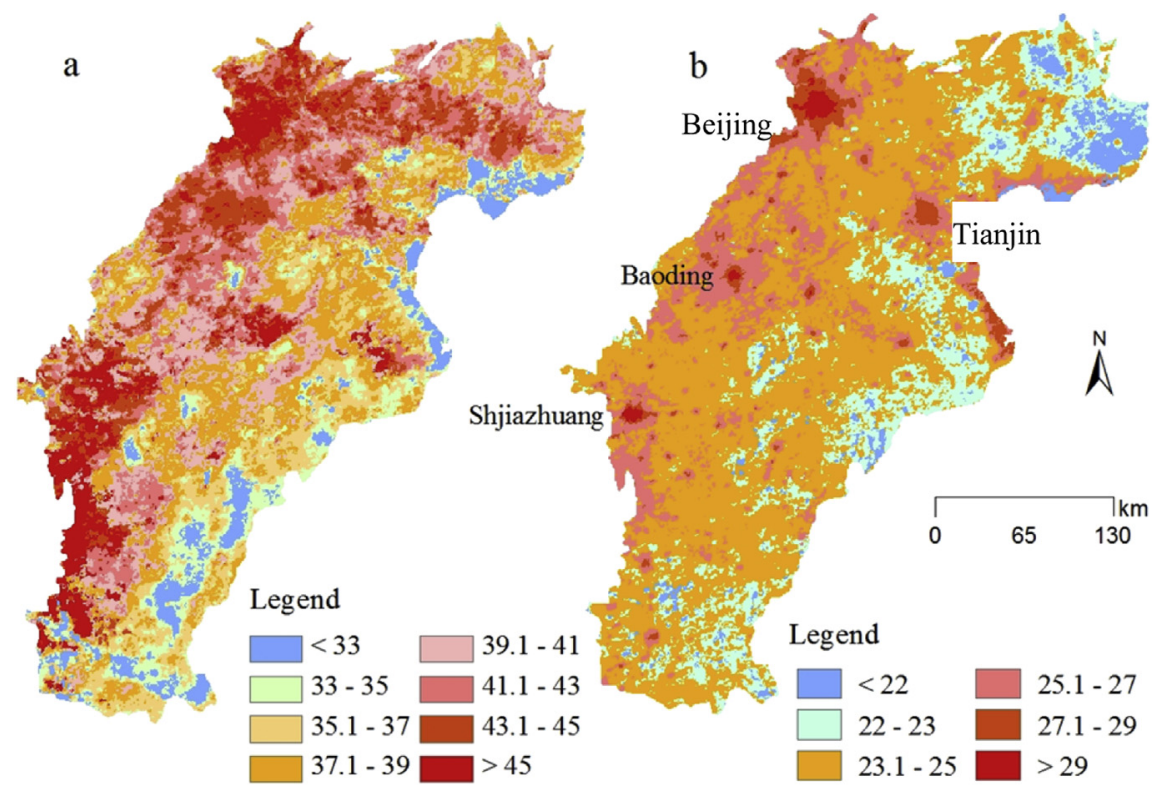

Fig. 3. Spatial patterns of (a) daytime LST $\left({ }^{\circ} \mathrm{C}\right)$ and (b) nighttime LST $\left({ }^{\circ} \mathrm{C}\right)$ in the Hebei Plain from July 4 th to July 11 th, 2010.

variable) variation that is explained. Correspondingly, the daytime value of $\mathrm{R}^{2}$ was about 0.306 , which was much lower than the nighttime value.

\section{Discussion}

There are many factors that affect UHII, such as topography and climatic differences. Thus, it is difficult to accurately estimate the
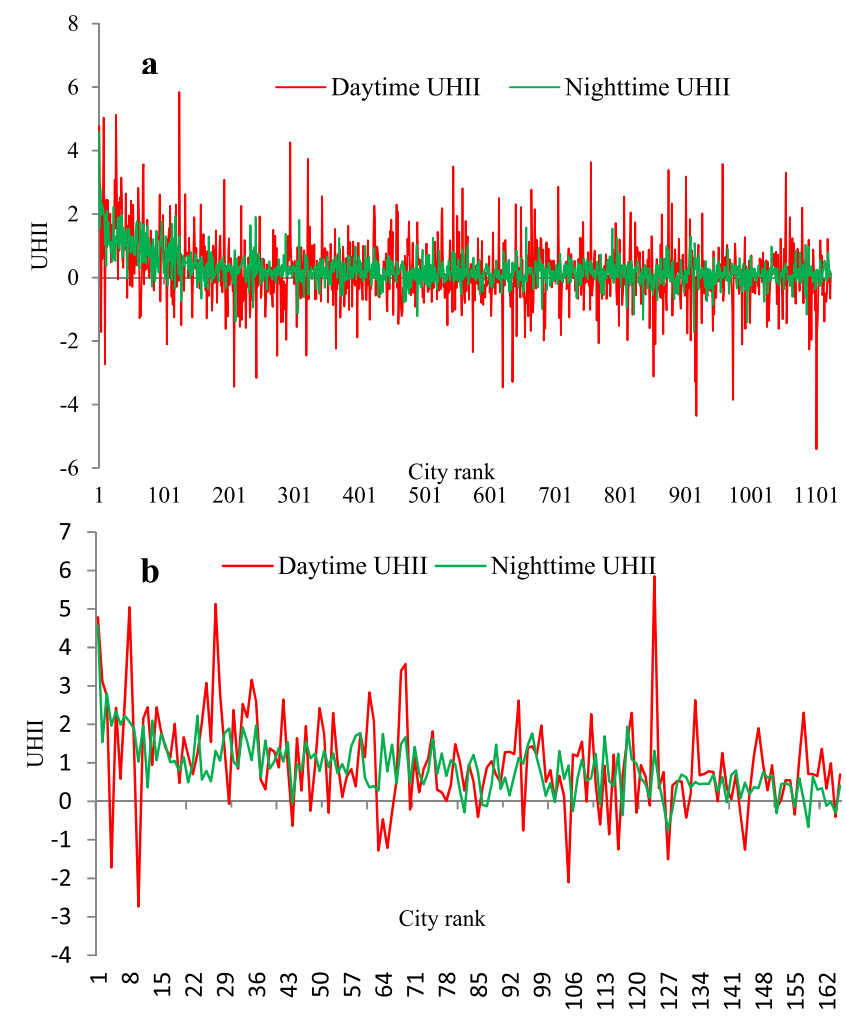

Fig. 4. Variation of urban heat island intensity $\left({ }^{\circ} \mathrm{C}\right)$ with city rank for (a) 1124 clusters and (b) 164 clusters with an area $>4 \mathrm{~km}^{2}$. Clusters were ranked from largest (rank 1 ) to smallest according to cluster area.

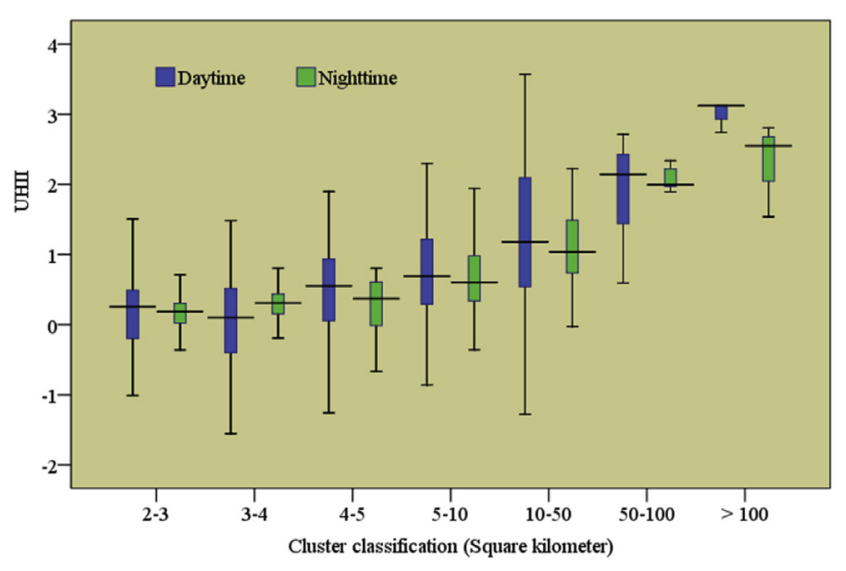

Fig. 5. Boxplot of daytime and nighttime urban heat island intensity $\left({ }^{\circ} \mathrm{C}\right)$ for different cluster sizes. The median is identified by the horizontal line in the box. The length of the box is the interquartile range. The outliers and extreme UHIIs were deleted using SPSS software.

effects of cluster size on UHII. We selected the Hebei Plain to examine the relationship between cluster size and UHII, because of its ideal geographical features, as discussed in the Introduction. In addition, the water bodies were removed in calculating the mean LSTs of the clusters and the surrounding areas. A simple method was used to define the suburban boundary of a cluster according to its radius.

The results showed that UHII were higher in the day than at night, especially for large cities. In this study, for cities with an area $>100 \mathrm{~km}^{2}$, the daytime mean UHII $\left(2.90{ }^{\circ} \mathrm{C}\right)$ was stronger than the nighttime mean UHI $\left(2.30^{\circ} \mathrm{C}\right)$. However, for smaller cities, the differences were small. For cities with an area between 2 and $3 \mathrm{~km}^{2}$, both day and night mean UHII were only $0.17^{\circ} \mathrm{C}$. The existing literature discusses the significance of daytime and nighttime UHII. Some research has found that UHII is greater in the day than at night (Schwarz, Lautenbach, \& Seppelt, 2011; Weng, 2009). During the daytime, impervious surfaces and high buildings in urban areas can modify the physical properties of the land surface, which may reduce surface albedo, total column water vapor, and cloudy fraction (Jin 

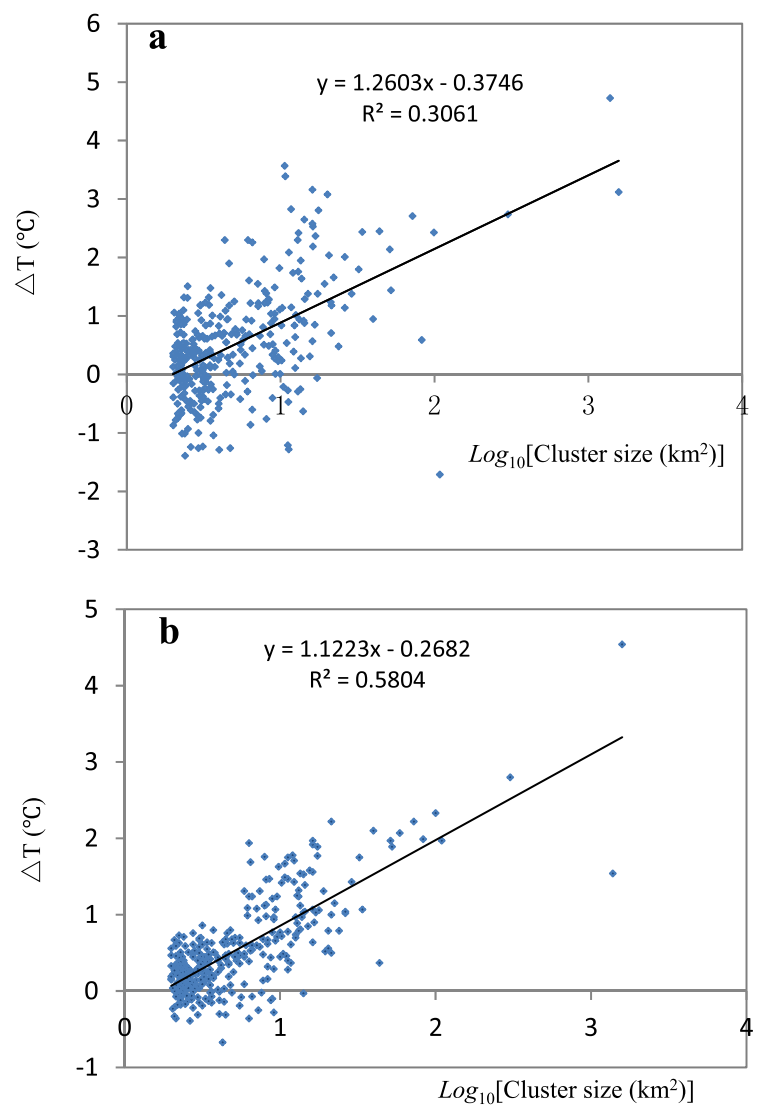

Fig. 6. Relationship between urban heat islands $\left({ }^{\circ} \mathrm{C}\right)$ and cluster size with an area $>2 \mathrm{~km}^{2}$ during the daytime (a) and nighttime (b).

et al., 2011). These result in the higher LST in urban built-up areas. In contrast, other studies have argued that the UHI effect occurs at night (Grimm et al., 2008; Kłysik \& Fortuniak, 1999), when buildings and streets release the solar heat absorbed during the day (Kalnay \& Cai, 2003). However, these arguments are often based on individual case studies or a limited number of cities. Consequently, the results are subject to uncertainty. Based on a large number of clusters, this study concluded that daytime UHII is more significant than nighttime UHII for clusters with an area $>2 \mathrm{~km}^{2}$ (Fig. 5). This is also confirmed by existing research where 45 cities in the USA ranging from $1 \mathrm{~km}^{2}$ to $>1000 \mathrm{~km}^{2}$ were studied (Imhoff et al., 2010). In addition, a study of 419 large global cities (Peng et al., 2012a,b) also showed that the average annual daytime UHII $\left(1.5 \pm 1.2^{\circ} \mathrm{C}\right)$ was higher than the annual nighttime UHII $\left(1.1 \pm 0.5{ }^{\circ} \mathrm{C} ; \mathrm{P}<0.001\right)$.
Cluster size was closely related to the UHII (Cai et al., 2011). In our study, the relationship can be described with a logarithmic function. Similarly, Imhoff et al. (2010) proposed that the relationship between the UHI amplitude and cluster size was log-linear, from a study of 45 cities in the USA. Using ten settlements, Oke (1973) also concluded that UHIs appeared to be approximately proportional to the fourth root of the population in summer in North American settlements, and that European towns and cities showed a similar relationship.

In our study, the regression results showed that during the night, the relationship between cluster size and UHII was stronger than during the day. For cities with a size $>2 \mathrm{~km}^{2}$, at night, the cluster size accounted for about $60 \%$ of the variance in UHII. In contrast, the proportion was about $30 \%$ in the daytime. In a case study of 45 cities in a temperate broadleaf mixed forest biome in continental USA (Imhoff et al., 2010), urban size accounted for about $71 \%$ of the variance in UHII.

In addition, for the clusters with an area $<2 \mathrm{~km}^{2}$, the relationship between UHI and cluster size was very weak. Fig. 7 shows that the values of $\mathrm{R}^{2}$ are 0.0038 and 0.0077 during the day and night, respectively, which means that cluster size has a very low explanatory power for daytime and nighttime UHII. This may arise for two reasons. First, for small settlements, the UHII is not significant, compared with the bigger settlements. Second, due to the low spatial resolution of MODIS data, it is difficult to check the LST differences between the clusters with an area $<2 \mathrm{~km}^{2}$ and their surrounding areas.

Based on these results, UHII increases with increasing cluster size (Fig. 6). This may have policy implications for urban planning and land use. To mitigate the UHII for large cities, it is necessary to control the increase in large built-up areas through developing new towns to house rural-urban migrants and urban overspill.

Previous studies also suggest that urban planning or land use can influence urban temperature and appropriate land use planning can mitigate the effects of UHI (Jusuf, Wong, Hagen, Anggoro, \& Hong, 2007).

Finally, the definition of the surrounding area has a significant effect on UHII. For instance, in a case study of all cities and towns in Europe (Zhou et al., 2013), a boundary around the urban cluster was approximately equal in area to the cluster, and it was concluded that UHI reached maximum saturation in summer (mean of up to $3{ }^{\circ} \mathrm{C}$ ). Our study did not show saturation for UHI, partly because we measured UHII using a larger surrounding area for clusters according to their radius. For a city, the mean value of the LST in a larger suburban area may better reflect the mean LST of the rural background. For example, in Beijing, the mean value of daytime LST within a buffer width of $0-500 \mathrm{~m}$ was $41.04{ }^{\circ} \mathrm{C}$, whereas it was $40.85^{\circ} \mathrm{C}$ within a $0-22000 \mathrm{~m}$ buffer (used in this study). Therefore,
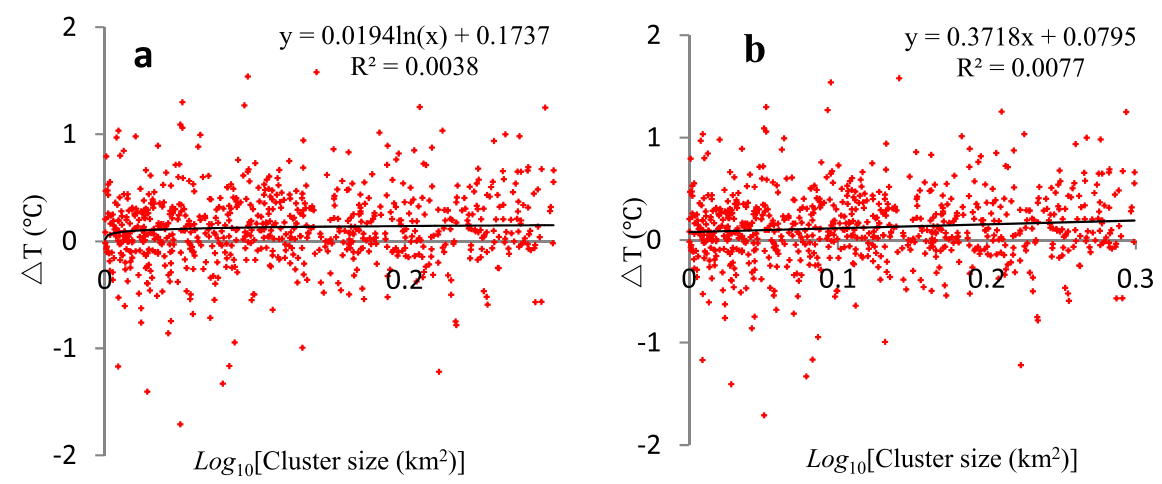

Fig. 7. Relationship between urban heat island intensity $\left({ }^{\circ} \mathrm{C}\right.$ ) and cluster size during (a) the daytime and (b) the nighttime for clusters $<2 \mathrm{~km}{ }^{2}$ in size. 


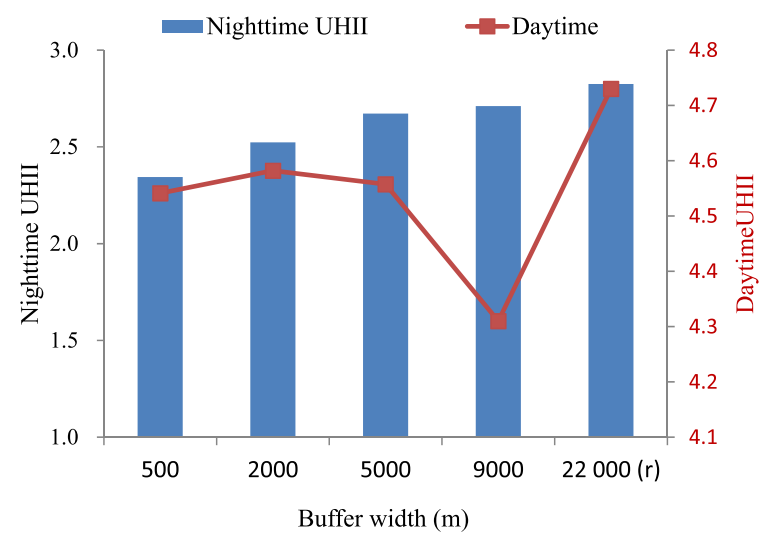

Fig. 8. Variation in urban heat island intensity $\left({ }^{\circ} \mathrm{C}\right)$ with buffer width in Beijing from July 4th to July 11th, 2010. Note: $22000 \mathrm{~m}$ was the buffer width calculated using Equation (1); $9000 \mathrm{~m}$ was the buffer width with an area equal to the cluster area.

the values of daytime UHII were 4.54 and $4.73{ }^{\circ} \mathrm{C}$ within these buffers, respectively (Fig. 8). Similarly, the daytime UHII in the buffer zone of 0-22 $000 \mathrm{~m}$ was also higher than that in the buffer of 0-9000 $\mathrm{m}$ (Fig. 8). The 0-9000 $\mathrm{m}$ buffer has been used in some previous studies (Zhou et al., 2013). Based on these findings, we suggest that the buffer width affected the calculation of UHII. This is consistent with previous studies (Imhoff et al., 2010; Peng et al., 2012a,b), which also concluded that the UHII was closely related to the buffer width.

\section{Conclusions}

We examined the relationship between city size and UHII using the Hebei Plain in China as a case study. The plain has ideal geographical features that can control the effect of the non-urban climate, including a large uniform area, similar biomes, and fewer water bodies than other large plains in China.

Cluster size showed a positive relationship with UHII. The relationship could be described using a logarithmic function. During the night, the relationship between cluster size and UHII was stronger than during the day. For cities $>2 \mathrm{~km}^{2}$ in size, the city size explained about $60 \%$ of the variance in nighttime UHII, whereas the proportion was about $30 \%$ during the daytime. For clusters $<2 \mathrm{~km}^{2}$ in size, the explanatory power was very weak, both during the day and night. These results may have policy implications for urban planning. To mitigate the UHI effect in large cities, it is necessary to control the increase in large built-up areas through developing new towns to house rural-urban migrants and urban overspill.

The results showed that UHIIs for the day were higher than those for the night, particularly for large cities. For cities with an area $>100 \mathrm{~km}^{2}$, the mean daytime UHII $\left(2.90^{\circ} \mathrm{C}\right)$ was greater than the nighttime UHII $\left(2.30^{\circ} \mathrm{C}\right)$. Based on an analysis of a large number of clusters, we concluded that daytime UHII is more significant than nighttime UHII for clusters with an area $>2 \mathrm{~km}^{2}$. This provides further insight into whether daytime UHII is more significant than nighttime UHII.

The standard deviations for daytime UHII and nighttime UHII were 1.03 and 0.49 , respectively. This confirmed that the UHII variations across cities were much greater in the day than at night.

The surrounding area exerts a direct effect on calculating UHII. We used buffers for 1124 clusters, and the buffer widths equaled the corresponding radius of the clusters. The buffer zones for the clusters were bigger than those in previous studies, thus the mean LSTs in the zones better reflect the LSTs of the rural background. This was proven by a case study of Beijing, which showed that the mean LSTs in the rural background decreased and the UHII increased with buffer width.

\section{Conflicts of interest}

The authors declare no conflict of interest.

\section{Acknowledgments}

This work was supported by the Natural Science Foundation of China (Grant No. 41271119 and 41161140352), National Basic Research Programme of China (Grant No. 2015CB452705) and the Ministry of Environmental Protection of the Peoples' Republic of China and CAS (Grant No. STSN-09-00).

\section{References}

Bart, I. L. (2010). Urban sprawl and climate change: a statistical exploration of cause and effect, with policy options for the EU. Land Use Policy, 27, 283-292.

Cai, G., Du, M., \& Xue, Y. (2011). Monitoring of urban heat island effect in beijing combining ASTER and TM data. International Journal of Remote Sensing, 32(5), 1213-1232.

Fabrizi, R., Bonafoni, S., \& Biondi, R. (2010). Satellite and ground-based sensors for the urban heat island analysis in the city of Rome. Remote Sensing, 2, $1400-1415$.

Grimm, N. B., Faeth, S. H., Golubiewski, N. E., Redman, C. L., Wu, J., Bai, X., et al. (2008). Global change and the ecology of cities. Science, 319, 756-760.

Hamada, S., \& Ohta, T. (2010). Seasonal variations in the cooling effect of urban green areas on surrounding urban areas. Urban Forestry\& Urban Greening, 9, $15-24$.

Hamdi, R. (2010). Estimating urban heat island effects on the temperature series of uccle (Brussels, Belgium) using remote sensing data and a land surface scheme. Remote Sensing, 2, 2773-2784.

Hung, T., Uchihama, D., Ochi, S., \& Yasuoka, Y. (2006). Assessment with satellite data of the urban heat island effects in asian mega cities. International Journal of Applied Earth Observation and Geoinformation, 8(1), 34-48.

Imhoff, M. L., Zhang, P., Wolfe, R. E., \& Bounoua, L. (2010). Remote sensing of the urban heat island effect across biomes in the continental USA. Remote Sensing of Environment, 114, 504-513.

Jin, M. S., Kessomkiat, W., \& Pereira, G. (2011). Satellite-observed urbanization characters in Shanghai, China: aerosols, urban heat island effect, and landatmosphere interactions. Remote Sensing, 3, 83-99.

Jusuf, S. K., Wong, N. H., Hagen, E., Anggoro, R., \& Hong, Y. (2007). The influence of land use on the urban heat island in Singapore. Habitat International, 31, $232-242$.

Kalnay, E., \& Cai, M. (2003). Impact of urbanization and land-use change on climate. Nature, 423, 528-531.

Kłysik, K., \& Fortuniak, K. (1999). Temporal and spatial characteristics of the urban heat island of Lódž, Poland. Atmospheric Environment, 33, 3885-3895.

Lin, C.-Y., Chen, F., Huang, J. C., Chen, W. C., Liou, Y. A., Chen, W. N., et al. (2008). Urban heat island effect and its impact on boundary layer development and land- sea circulation over northern Taiwan. Atmospheric Environment, 42, 5635-5649.

Lin, W., Wu, T., Zhang, C., \& Yu, T. (2011). Carbon savings resulting from the cooling effect of green areas: a case study in Beijing. Environmental Pollution, 159, 2148-2154.

Ma, Y., Kuang, Y., \& Huang, N. (2010). Coupling urbanization analyses for studying urban thermal environment and its interplay with biophysical parameters based on TM/ETM+ imagery. International Journal of Applied Earth Observation and Geoinformation, 12, 110-118.

Nakayama, T., \& Fujita, T. (2010). Cooling effect of water-holding pavements made of new materials on water and heat budgets in urban areas. Landscape and Urban Planning, 96, 57-67.

Nichol, J. (2005). Remote sensing of urban heat islands by day and night. Photogrammetric Engineering Remote Sensing, 21(5), 613-621.

Oke, T. R. (1973). City size and the urban heat island. Atmospheric Environment, 7, $769-779$.

Oliveira, S., Andrade, H., \& Vaz, T. (2011). The cooling effect of green spaces as a contribution to the mitigation of urban heat: a case study in Lisbon. Building and Environment, 46(11), 2186-2194.

Peng, S., Piao, S., Ciais, P., Friedlingstein, P., Ottle, C., Breon, F. o.-M., et al. (2012). Response to comment on "Surface urban heat island across 419 global big cities". Environmental.Science \& Technology, 46, 6889-6890.

Peng, S., Piao, S., Ciais, P., Friedlingstein, P., Ottle, C., Breon, F. o.-M., et al. (2012). Surface urban heat island across $419 \mathrm{global}$ big cities. Environmental.Science \& Technology, 46, 696-703.

Research Center for Eco-Environmental Sciences, Chinese Academy of Sciences (RCEES). (2013). National ecological environment decade change assessment database system. http://wps1.gscloud.cn/index.shtml.

Schwarz, N. (2012). Comment on "Surface urban heat island across 419 global big cities”. Environmental.Science \& Technology, 46, 6888-6888. 
Schwarz, N., Lautenbach, S., \& Seppelt, R. (2011). Exploring indicators for quantifying surface urban heat islands of european cities with MODIS land surface temperatures. Remote Sensing of Environment, 115, 3175-3186.

Steeneveld, G. J., Koopmans, S., Heusinkveld, B. G., Van Hove, L. W. A., \& Holtslag, A. A. M. (2011). Quantifying urban heat island effects and human comfort for cities of variable size and urban morphology in the Netherlands. Jounal of Geophysical Research, 116, D20129. http://dx.doi.org/20110.21029/ 22011JD015988.

Streutker, D. R. (2002). A remote sensing study of the urban heat island of Houston, Texas. International Journal of Reomote Sensing, 23(13), 2595-2608.

Tan, M., \& Li, X. (2013). Integrated assessment of the cool island intensity of green spaces in the mega city of Beijing. International Journal of Reomote Sensing, 34(8), 3028-3043.

Wan, Z. (2008). New refinements and validation of the MODIS land-surface temperature/emissivity products. Remote Sensing of Environment, 112, 59-74.

Wang, B., Jin, M., Nimmo, J. R., Yang, L., \& Wang, W. (2008). Estimating groundwater recharge in hebei Plain, China under varying land use practices using tritium and bromide tracers. Journal of Hydrology, 356, 209-222.

Wang, K., Wang, J., Wang, P., Sparrow, M., Yang, J., \& Chen, H. (2007). Influences of urbanization on surface characteristics as derived from the moderateresolution imaging Spectroradiometer: a case study for the beijing metropolitan area. Journal of Geophysical Research, 112, D22S06. http://dx.doi.org $10.1029 / 2006 J D 007997$.

Weng, Q. (2009). Thermal infrared remote sensing for urban climate and environmental studies: methods, applications, and trends. Journal of Photogrammetry and Remote Sensing, 64, 335-344.

Wong, N. H., \& Yu, C. (2005). Study of green areas and urban heat island in a tropical city. Habitat International, 29, 547-558.

Wu, H., Ye, L. P., Shi, W. Z., \& Clarkec, K. C. (2014). Assessing the effects of land use spatial structure on urban heatislands using $\mathrm{HJ}-1 \mathrm{~B}$ remote sensing imagery in Wuhan, China. International Journal of Applied Earth Observation and Geoinformation, 32, 67-78.

Zhang, X., Zhong, T., Deng, X., \& Wang, K. (2009). Estimation of the relationship between vegetation patches and urban land surface temperature with remote sensing. International Journal of Remote Sensing, 30(8), 2105-2118.

Zhou, B., Rybski, D., \& Kropp, J. P. (2013). On the statistics of urban heat island intensity. Geophysical Research Letters, 40, 5486-5491. 